The Canadian Mineralogist

Vol. 45, pp. 551-557 (2007)

DOI: $10.2113 /$ gscanmin. 45.3 .551

\title{
THE ORIGIN OF COLOR IN “FIRE” OBSIDIAN
}

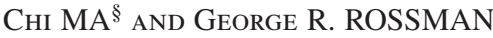

Division of Geological and Planetary Sciences, California Institute of Technology, Pasadena, California 91125, U.S.A.

\author{
JAMES A. MILLER
}

GeoEngineers, Inc., Redmond, Washington 98052, U.S.A.

\begin{abstract}
A variety of obsidian from Glass Buttes, Oregon, known as "fire" obsidian and named for thin layers showing various colors, was investigated with field-emission scanning electron microscopy, X-ray energy-dispersive spectroscopy, electron back-scatter diffraction, and optical spectroscopy methods. Our study reveals that the thin layers mainly consist of concentrated nanometric crystals of magnetite. The thin layers, which have a thickness of 300 to $700 \mathrm{~nm}$, give rise to brilliant colors in reflection. The color is caused by thin-film optical interference, in which the thin layers have a higher calculated index of refraction $(1.496<n$ $<1.519)$ than that of the host glass $(n=1.481)$.
\end{abstract}

Keywords: "fire" obsidian, nanometric magnetite, thin-film interference, Glass Buttes, Oregon.

\section{SOMMAIRE}

Nous avons caractérisé une variété d'obsidienne provenant de Glass Buttes, en Orégon, nommée obsidienne “de feu” à cause de minces couches de couleurs variées, au moyen de microscopie électronique à balayage avec champ d'émission, spectroscopie des rayons $\mathrm{X}$ en dispersion d'énergie et diffraction d'électrons rétrodiffusés. Notre étude montre que les minces couches contiennent une concentration de cristaux nanométriques de magnétite. Ces couches de cristaux, d'une épaisseur de 300 à $700 \mathrm{~nm}$, produisent les couleurs brillantes en réflection. La couleur est due à une interférence optique de pellicules minces, dans laquelle les couches possèdent un indice de réfraction plus élevé $(1.496<n<1.519)$ que celui du verre hôte $(n=1.481)$.

(Traduit par la Rédaction)

Mots-clés: obsidienne “de feu”, magnétite nanométrique, interférence optique de pellicules minces, Glass Buttes, Orégon.

\section{INTRODUCTION}

Obsidian usually occurs as black volcanic glass. Colored varieties of obsidian also occur, like rainbow obsidian from Mexico, California and Oregon. "Fire" obsidian is a rare variety of relatively clear volcanic glass that produces vibrant color-reflectance from isolated thin layers contained within the stone (Fig. 1). Color patterns are quite variable and are generally unique from sample to sample from the same locality.

The color of fire obsidian appears to come from reflections from distinct, but uncharacterized, thin layers within the glass, whereas the color of rainbow obsidian occurs from a much thicker volume of the sample (Ma et al. 2001). The objective of this study is to determine the detailed origin of color in fire obsidian and to char-

§E-mail address: chi@gps.caltech.edu acterize the obsidian down to a nanometer scale using advanced analytical methods.

\section{The Oregon Occurrence of Fire Obsidian}

The samples of fire obsidian studied in this paper were collected at Glass Buttes in east-central Oregon, USA. This volcanic highland is an extinct rhyolite dome that comprises about $90 \mathrm{~km}^{2}$ at altitudes of 1,400 to $1,950 \mathrm{~m}$. Most of the volcanic deposits at Glass Buttes are 4 to 5 million years old, on the basis of potassium-argon age dating (Walker et al. 1974, Walker \& MacLeod 1991). Post-eruption weathering and erosion have removed much of the youngest volcanic deposits, locally exposing older sections of the rhyolite dome. Additional details about the sampling locale are found in Miller (2006). 
Hand-dug excavations up to $2 \mathrm{~m}$ deep were made to examine the fire obsidian in situ and to collect samples for analysis. The fire obsidian occurs within thin, nearvertical dikes that penetrate older, pink-colored rhyolite. Typically about 5 to $20 \mathrm{~cm}$ thick, these dikes originally conveyed felsic magma to obsidian flows at the ground surface. The surface obsidian flows have long since been eroded away at the sampling location, but the obsidian feeder dikes remain in the underlying rhyolite host-rock (Fig. 2).

Some of the obsidian dikes exposed in the hillside excavations contain isolated thin layers within the obsidian. These thin layers are almost invisible if viewed from the side, but they appear as dark surfaces if examined at an oblique angle to the orientation of the layers. In many cases, multiple thin, submillimetric layers occur within a specific obsidian dike. These thin layers are typically aligned parallel to each other and nearly parallel to the orientation of the walls of the obsidian dikes, from which we deduce that these are flow-aligned layers. Only some obsidian dikes contain the thin layers, and only some of the thin layers produce colorful reflectance.

Field exposures generally indicate that the obsidian dikes split around intact pieces of the rhyolite hostrock, and then the dikes rejoin above the block of intact bedrock. In the case of the fire obsidian dikes, the high viscosity of the felsic magma prevented mixing of the magma across flow lines within the dikes. Distinct layers within the dikes remain separate after repeated splitting and rejoining of the obsidian during its upward journey through the host rock. The fire obsidian dikes record the last phase of movement of the magma before it congealed, preserving the flow lines in the dikes as thin layers. One of our main objectives is to discover what distinguishes the contrasting layers within the fire obsidian.

\section{EXPERIMENTAL}

Fire obsidian and clear black obsidian specimens from Glass Buttes were selected for this study. Fresh fracture-surfaces were prepared for examination with a scanning electron microscope.

Secondary electron (SE) and back-scattered electron (BSE) images were obtained with a LEO 1550VP fieldemission scanning electron microscope (FE-SEM). An Oxford INCA X-ray energy-dispersive spectrometer (EDS) on the SEM was used for elemental analysis. Quantitative analyses were processed with the XPP correction procedure (Pouchou \& Pichoir 1991). Electron back-scatter diffraction (EBSD) analyses at a submicrometer scale were performed using an HKL EBSD system on the LEO $1550 \mathrm{VP}$, operated at $20 \mathrm{kV}$ and $1 \mathrm{nA}$ in a focused beam with a $70^{\circ}$ tilted stage. A silicon single crystal was used to calibrate the EBSD system.
Optical absorption measurements of the intrinsic obsidian color were obtained on a slab $2.164 \mathrm{~mm}$ thick with polished surfaces approximately normal to the plane of the color. They were carried out using a diode array spectrometer system with both silicon and InGaAs diode arrays for extended coverage in terms of wavelengths.

\section{RESULTS}

\section{Optical observations}

Hand samples of fire obsidian show thin, subplanar features (layers) that can generally be recognized by their apparent darker color. The layers are scattered throughout the glass; most are relatively flat and locally parallel to each other (Fig. 3a) and appear to follow the melt-flow direction. Throughout the obsidian, fine opaque inclusions were found in all examined black and colored samples under reflected-light optical microscope. The inclusions are concentrated in the thin layers. Lines and bands of inclusions are obvious on some thin layers (Figs. 3b, c). The direction of the lines is also likely to be the melt-flow direction. Some of the thin layers in fire obsidian display color reflectance (Fig. 3d).

\section{Obsidian composition}

Elemental compositions of the obsidian and thin layers obtained by EDS are presented in Table 1. The glass composition of fire obsidian is similar to that of the black obsidian, whereas the darker, thin layers have a much higher $\mathrm{FeO}$ concentration (total $\mathrm{Fe}$ expressed as $\mathrm{FeO}$ ). The index of refraction of fire obsidian was calculated using the chemical composition method of Church \& Johnson (1980). The thin layers have a higher

TABLE 1. BULK COMPOSITION OF THE GLASS BUTTES OBSIDIAN

\begin{tabular}{|c|c|c|c|c|c|c|c|}
\hline \multirow[b]{2}{*}{$\mathrm{SiO}_{2}$ wt. $\%$} & \multirow{2}{*}{$\begin{array}{l}\text { Glass } \\
77.53\end{array}$} & \multicolumn{3}{|c|}{$\begin{array}{c}\text { Layer } 1 * \text { Layer } 2 \text { Layer } 3 \\
\text { Fire obsidian (this study) }\end{array}$} & \multirow{2}{*}{$\begin{array}{c}\text { Layer } 4 \\
72.31\end{array}$} & \multicolumn{2}{|c|}{$\begin{array}{l}\text { Glass Buttes } \\
\text { obsidian } \\
\text { Ihinger (1991) }\end{array}$} \\
\hline & & 76.06 & 74.24 & 74.24 & & 77.61 & 77.70 \\
\hline $\mathrm{TiO}_{2}$ & 0.29 & 0.00 & 0.30 & 0.14 & 0.19 & 0.06 & 0.10 \\
\hline $\mathrm{Al}_{2} \mathrm{O}_{3}$ & 12.39 & 11.87 & 11.87 & 11.72 & 11.68 & 12.92 & 12.97 \\
\hline $\mathrm{FeO}$ & 0.62 & 4.02 & 4.45 & 5.76 & 9.07 & 0.36 & 0.71 \\
\hline $\mathrm{MnO}$ & 0.02 & 0.28 & 0.14 & 0.04 & 0.00 & 0.03 & 0.03 \\
\hline $\mathrm{MgO}$ & 0.01 & 0.19 & 0.10 & 0.00 & 0.05 & 0.04 & 0.05 \\
\hline $\mathrm{CaO}$ & 0.72 & 0.59 & 0.69 & 0.77 & 0.72 & 0.52 & 0.53 \\
\hline $\mathrm{Na}_{2} \mathrm{O}$ & 3.31 & 3.35 & 2.74 & 2.74 & 2.59 & 4.18 & 4.06 \\
\hline $\mathrm{K}_{2} \mathrm{O}$ & 4.12 & 3.91 & 4.12 & 3.90 & 3.26 & 4.17 & 4.18 \\
\hline Total & 99.01 & 100.27 & 98.66 & 99.31 & 99.85 & 99.89 & 100.33 \\
\hline $\begin{array}{l}\text { Index of } \\
\text { refraction }(n)^{*}\end{array}$ & 1.481 & 1.500 & 1.496 & 1.503 & 1.519 & 1.482 & 1.486 \\
\hline
\end{tabular}

\footnotetext{
* Representative individual layers in the obsidian. Calculated values.
} 
index of refraction ( $n$ in the range 1.496-1.519) than that of the obsidian $(n=1.481)$.

\section{Color of the obsidian}

The color of a slab of obsidian $2.164 \mathrm{~mm}$ thick was compared to Munsell System color chips. Although such obsidian is commonly called black, at this thickness, it does have a noticeable color corresponding to about 5YR 7/2 in the Munsell System (1976), which corresponds to pinkish brown in the NBS nomenclature (Kelly \& Judd 1976). The black obsidian without thin layers from Glass Buttes contains evenly distributed inclusions of magnetite. The darker the black obsidian, the more numerous the magnetite crystals or the larger the crystals are in size (up to $15 \mu \mathrm{m}$ ).

\section{Optical absorption spectra}

To distinguish between the features responsible for the "fire" in the obsidian, it is first necessary to determine the spectroscopic properties of the obsidian. Figure 4 shows the optical absorption spectrum of a slab of the obsidian $2.164 \mathrm{~mm}$ thick, taken from the region that shows "fire" but using an orientation that minimizes the fire effect upon the spectrum. The dominant absorption band at about $1120 \mathrm{~nm}$ arises from $\mathrm{Fe}^{2+}$ in the glass (Faulques et al. 2001). The transmission maximum at about $750 \mathrm{~nm}$ is responsible for the pinkish brown transmission color of the glass. The minor change in slope near $420 \mathrm{~nm}$ is in the position of $\mathrm{Fe}^{3+}$ bands in silicate glasses.

A weak band near $550 \mathrm{~nm}$ also contributes to the transmission color of the obsidian. Although Nolet et al. (1979) assigned a band at $550 \mathrm{~nm}$ to $\mathrm{Ti}^{3+}$, this is not a realistic oxidation state for $\mathrm{Ti}$ in crustal rocks, as evidenced by the general inability to find $\mathrm{Ti}^{3+}$ in numerous minerals by direct Ti X-ray absorption nearedge studies (e.g., Waychunas 1987). It is more likely that absorption in this region is due to intervalence charge-transfer between $\mathrm{Fe}^{2+}$ and either $\mathrm{Fe}^{3+}$ or $\mathrm{Ti}^{4+}$, as has been shown to be the case for lunar glasses, which form under more reducing conditions (Ashikhmina et al. 1990).

\section{SEM observations}

SEM imaging and EDS analysis reveal that all the darker, thin layers are highly enriched in iron oxide nano-inclusions, as shown in Figure 5. The nano-inclusions have an isometric shape and range in size from 80 to $110 \mathrm{~nm}$ in width. The thickness of thin layers with color varies from 300 to $700 \mathrm{~nm}$. Scattered larger, irregular inclusions (typically ranging from 400 to 1000 $\mathrm{nm}$, and occasionally up to $3 \mu \mathrm{m}$ ) also occur, both in the layers and in the glass.

\section{Identification of particles}

The iron oxide inclusions are identified to be magnetite by electron back-scatter diffraction. The detected Kikuchi bands in the EBSD pattern of the iron oxide inclusions were matched perfectly with the simulated bands from the ideal structure of magnetite (Wechsler et al. 1984), as shown in Figure 6. The inclusions thus are magnetite. No other type of inclusions was found. The EBSD method is uniquely suited for in situ identification of crystalline phases that range down to submicrometer scales (Michael 2000) and is of importance in the study of micro- and nanomineralogy.

\section{INTERPRETATIONS AND DISCUSSION}

Thin layers enriched in magnetite nanocrystals in obsidian are the cause of the "fire" coloration. Measurements of the layer thickness and the estimated index of refraction indicate that some of the layers are of an appropriate thickness to cause thin-film interference. The layers have both a higher calculated index of refraction than the host obsidian and have a thickness slightly less than the wavelength of visible light. Such conditions are ideally suited to giving interference colors similar to those from a thin slick of oil on water. Further indication that the color is an interference phenomenon comes from the observation that the color on a fixed point of the obsidian varies as the sample is rotated along an axis perpendicular to the line of sight. Back-scattered-electron images do not indicate an enrichment of iron in the glass component of the thin layer compared to the bulk obsidian, thus ruling out the possibility that the interference is due solely to a higher index of refraction from a glass of higher iron content.

Magnetite inclusions seem abundant in the Glass Buttes obsidian. Black obsidian from other localities probably contains magnetite nanocrystals as well. At Glass Buttes, the magnetite nano-inclusions are presumably a significant contribution to the black color of obsidian. Where the magnetite inclusions concentrate to form thin layers of a submicrometric thickness, the "fire" coloration may appear. If the thin layers are a few micrometers thick, the layers show a dark grey color in transmission and in reflection.

Interestingly, the magnetite nanocrystals that occur in obsidian from Glass Buttes show some similarities to magnetite crystals of biological origin. They are both chemically and structurally pure, ranging from 80 to $110 \mathrm{~nm}$ in size.

\section{ACKNOWLEDGEMENTS}

FE-SEM, EDS and EBSD analyses were done at the Caltech GPS analytical facility, which is supported 

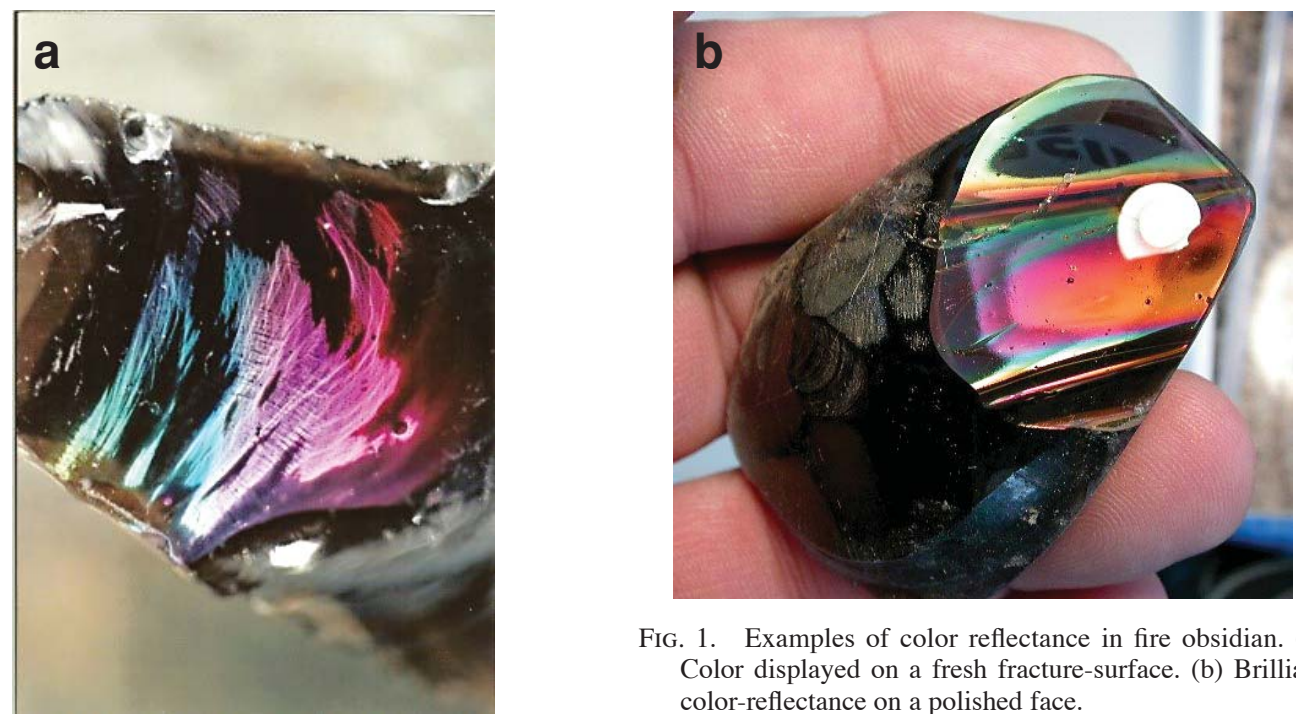

FIG. 1. Examples of color reflectance in fire obsidian. (a) Color displayed on a fresh fracture-surface. (b) Brilliant color-reflectance on a polished face.

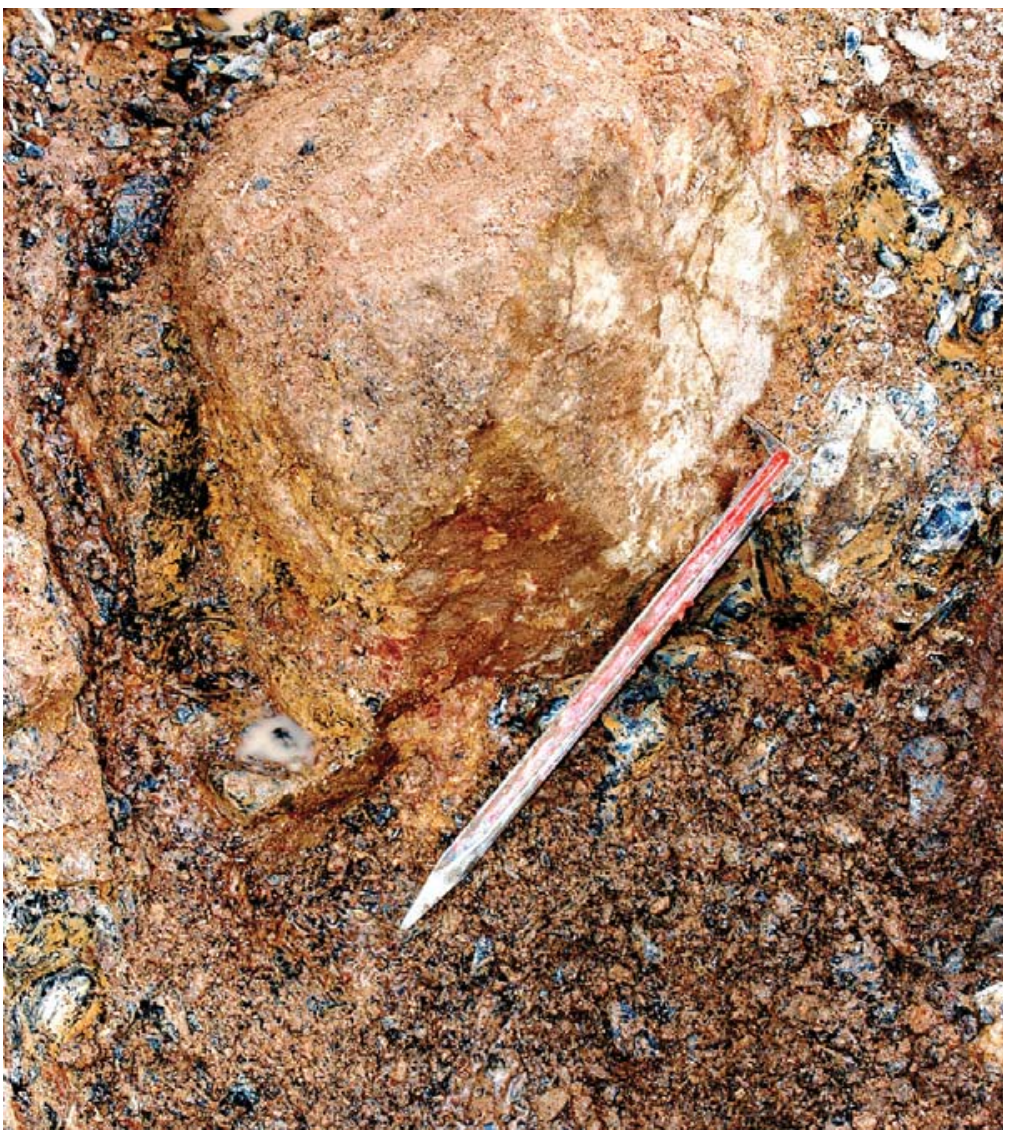

FIG. 2. Photo showing intact rhyolite host-rock surrounded by thin, weathered obsidian dikes. The obsidian dike on the right side of the rhyolite does not contain fire obsidian, whereas the obsidian to the left of the rhyolite has multiple thin layers with color reflectance. 

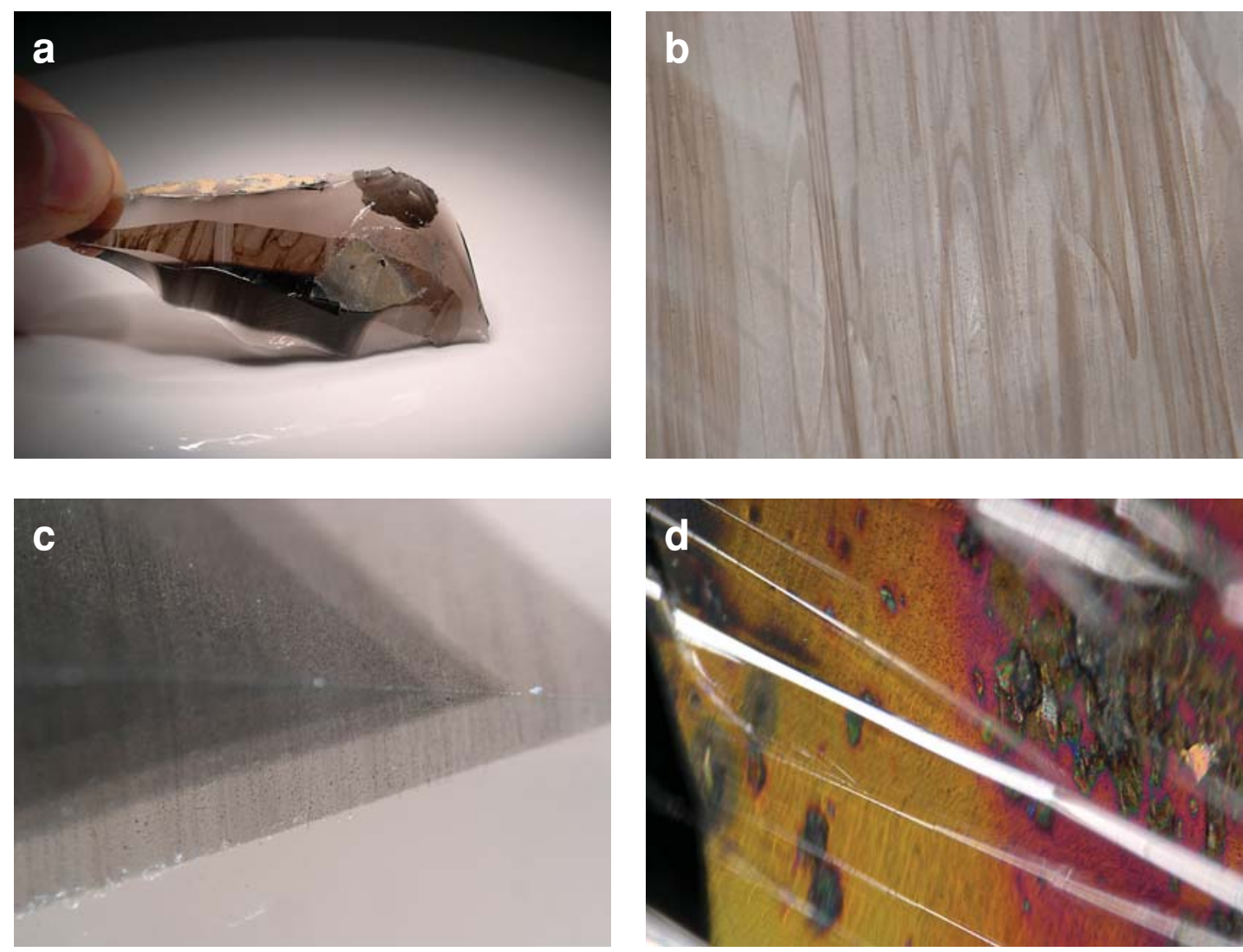

FIG. 3. Reflected-light optical images. (a) Fracture surface of fire obsidian through which dark bands can be seen. (b) Lines of magnetite. (c) Thin, darker layers in fire obsidian. (d) Colors in fire obsidian from light reflected off a layer. The field of view is $1.8 \mathrm{~mm}$ wide in Figures $3 \mathrm{~b}, 3 \mathrm{c}$ and $3 \mathrm{~d}$.

in part by the MRSEC Program of the NSF under DMR-0080065. Additional support was provided to G.R.R. through NSF grant EAR-0337816. A special "thank you" is extended to Nadine and Don Carey, owners of the fire obsidian claim, who granted permission to collect samples. The photos of fire obsidian shown in Figure 1 were supplied by Steve Sayer for this publication.

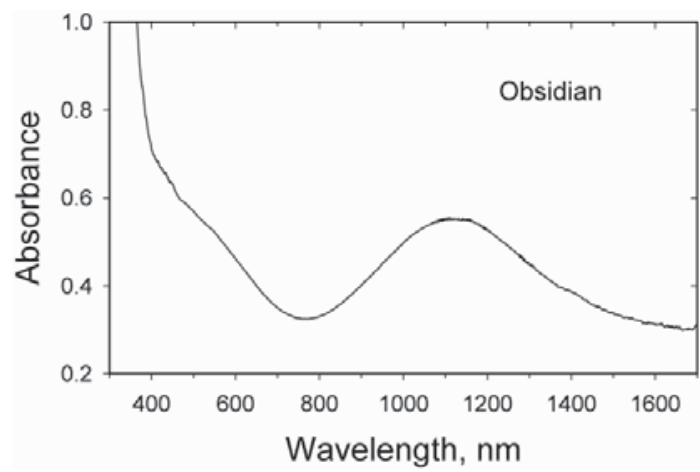

FIG. 4. Optical absorption spectrum of a polished slab of the fire obsidian $2.164 \mathrm{~mm}$ thick, taken in a region away from the zone that causes the "fire". 

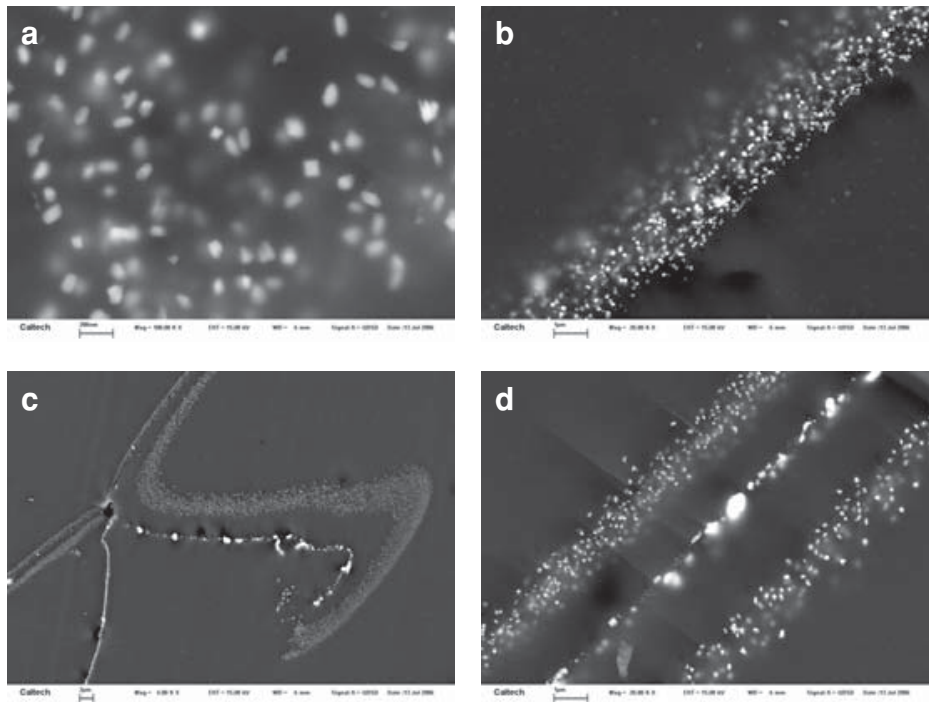

FIG. 5. SEM images reveal that thin layers consist of magnetite inclusions. (a) Magnetite nanocrystals within a thin layer. (b) A thin layer reflecting a green color. (c) Folded layers. (d) Three parallel layers. In all images, the layers run in and out of the plane of the image. The scale bars are equal to $200 \mathrm{~nm}$ (a), $1 \mu \mathrm{m}$ (b and d), and $2 \mu \mathrm{m}$ (c).
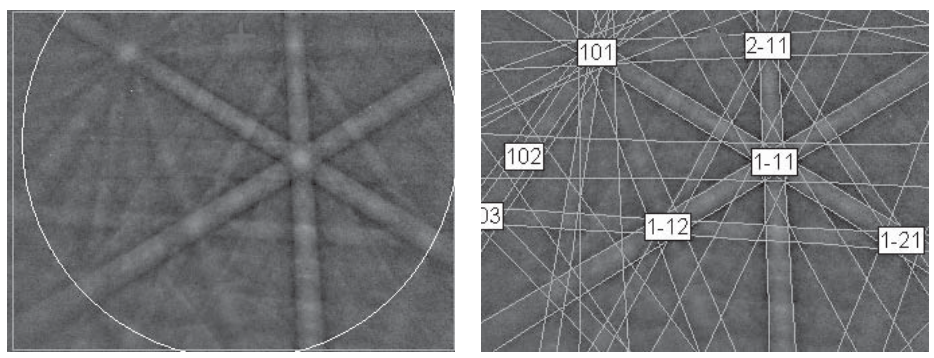

FIG. 6. (a) EBSD pattern of a micrometric crystal of magnetite in Figure 5c. (b) The pattern is perfectly indexed with the magnetite structure.

\section{REFERENCES}

Ashikhmina, N.A., Bogatikov, O.A., TARAn, M.N. \& FrikHKHAR, D.I. (1990): Order in lunar glasses as detected by optical spectroscopy. Dokl. Akad. Nauk SSSR 311(3), 729732 (in Russ.)

Church, B.N. \& Johnson, W.M. (1980): Calculation of the refractive index of silicate glasses from chemical composition. Geol. Soc. Am., Bull. 91, 619-625.

Faulques, E., Fritsch, E. \& Ostroumov, M. (2001): Spectroscopy of natural silica-rich glasses. J. Mineral. Petrol. Sci. 96, 120-128.
IHINGER, P.D. (1991): An Experimental Study of the Interaction of Water with Granitic Melt. Ph.D. thesis, California Institute of Technology, Pasadena, California.

Kelly, K.L. \& Judd, D.B. (1976): Color. Universal Language and Dictionary of Names. U.S. Department of Commerce, National Bureau of Standards, Spec. Publ. 440.

Ma, Chi, Gresh, J., Rossman, G.R., Ulmer, G.C. \& Vicenzi, E.P. (2001): Micro-analytical study of the optical properties of rainbow and sheen obsidians. Can. Mineral. 39 , 57-71. 
Michael, J.R. (2000): Phase identification using electron backscatter diffraction in the scanning electron microscope. In Electron Backscatter Diffraction in Material Science (A.J. Schwartz, M. Kumar \& B.L. Adams, eds.). Kluwer Academic/Plenum Publishers, New York, N.Y. (75-89).

Miller, J.A. (2006): Fabulous fire obsidian. Rock and Gem 36(1), 60-64.

Munsell Color Company (1976): Munsell Book of Color. Munsell Color, Baltimore, Maryland.

Nolet, D.A., Burns, R.G., Flamm, S.L. \& Besancon, J.R. (1979): Spectra of iron-titanium silicate glasses: implications to remote-sensing of planetary surfaces. Geochim. Cosmochim. Acta, Suppl. 11 (Proc. Lunar Planet. Sci. Conf., 10th, 2), 1775-1786.

Pouchou, J.-L. \& PichoIr, F. (1991): Quantitative analysis of homogeneous or stratified microvolumes applying the model "PAP". Electron Probe Quantitation (K.F.J. Heinrich \& D.E. Newbury, eds.). Plenum Press, New York.
WAlKer, G.W., DALrymple, G.B. \& LANPhere, M.A. (1974): Index to potassium-argon ages of Cenozoic volcanic rocks of Oregon. U.S. Geol. Surv., Misc. Invest. Ser., Field Studies Map MF-569 (scale 1:1,000,000).

WALKer, G.W. \& MacLeod, N.S. (1991): Geologic Map of Oregon. U.S. Geol. Surv., Map 32383. (scale 1:500,000).

WAYChunAs, G.A. (1987): Synchrotron radiation XANES spectroscopy of titanium in minerals: effects of titanium bonding distances, titanium valence, and site geometry on absorption edge structure. Am. Mineral. 72, 89-101.

Wechsler, B.A., Lindsley, D.H. \& PrewitT, C.T. (1984): Crystal structure and cation distribution in titanomagnetites $\left(\mathrm{Fe}_{3-x} \mathrm{Ti}_{x} \mathrm{O}_{4}\right)$. Am. Mineral. 69, 754-770.

Received January 6, 2006; revised manuscript accepted September 15, 2006. 